\title{
Recovery of copper and cobalt in the comparative flotation of a sulfide ore using xanthate and dithiophosphate as collectors
}

\author{
Meschack Muanda Mukunga
}

\begin{abstract}
Copper and cobalt are two major metals used in industry. They play a role in widely many domains like that electricity, chemistry and electrochemistry. They are contained into several minerals like chalcopyrite, carrolite, chalcocite, etc. associated to pyrite. The froth flotation and behaviors of chalcocite and carrolite were investigated through many flotation tests in order to recovery copper and cobalt. This paper investigates the effect of potassium amyl xanthate (PAX) and sodium dibutyl dithiophosphate (DANA) performance on both copper and cobalt recovery in single roughing flotation. The effect of $\mathrm{pH}$ on the flotation is proposed. Some parameters were kept constant such as particle size $\mathrm{d80}=75 \mu \mathrm{m}$, pulp density $10 \%$ solids, impeller speed $1300 \mathrm{rpm}$, and PAX doses of DANA (105 $\mathrm{g} / \mathrm{t}$ per each) as collectors, dose of DF250 ( 5 drops) as frother, dose of $\mathrm{Na}_{2} \mathrm{SiO}_{3}(200 \mathrm{~g} / \mathrm{t})$ as dispersant and depressant. Only the pulp pH was varied from the natural $\mathrm{pH}$ to 11 , using $\mathrm{Ca}(\mathrm{OH})_{2}$ as regulator. According to results, PAX (105 g/t) was found as the best collector for recovery of copper both at natural $\mathrm{pH}$ and $\mathrm{pH}=11$. At natural $\mathrm{pH}$, the concentrate was found at $16.1 \%$ copper recovery with a yield of $99.63 \%$. At $\mathrm{pH}=11$, the concentrate was found at $16.1 \%$ copper recovery with a yield of $99.05 \%$. For the recovery of cobalt, DANA $(105 \mathrm{~g} / \mathrm{t})$ was found better as the collector at natural $\mathrm{pH}$ producing a concentrate at $0.51 \%$ cobalt recovery yield of $76.48 \%$. At $\mathrm{pH}=11$, PAX (105 $\mathrm{g} / \mathrm{t}$ ) was found better as the collector. The concentrate was found at $0.91 \%$ cobalt with a recovery yield of $85.13 \%$.
\end{abstract}

Index Terms - cobalt, copper, dithiophosphate, flotation, xanthate.

\section{INTRODUCTION}

The evolution of technology has led the development of several mining techniques for base metals that are most used. Copper and cobalt are part and are contained in the oxidized minerals, sulphide or mixed. They are used in several disciplines: electricity, robotics, battery manufacturing, metal alloys, machine building, and the list is not exhaustive [5], [9], [11], [19].

Copper is a strategic metal and its demand is growing rapidly [15]. Cobalt has also a great role for the growth of humans, animals and plants. However, it cannot be taken to avoid excessively toxic effects. [17]. Copper-cobalt ore from copper and cobalt come from the Central African Copper Belt in the Democratic Republic of Congo and Zambia.

Copper sulfide minerals are chalcopyrite $\mathrm{CuFeS}_{2}$, chalcocite $\mathrm{CuS}_{2}$, bornite $\mathrm{Cu}_{5} \mathrm{FeS}_{4}$. Cobalt sulfide minerals are cobaltine

Meschack Muanda Mukunga, Department of Chemical and Metallurgical Engineering, University of the Witwatersrand, Johannesburg, South Africa
$(\mathrm{CoAsS})$, carrollite $\left(\mathrm{Cu}\left(\mathrm{Co} . \mathrm{Ni}_{2} \mathrm{~S}_{4}\right)\right.$ and linneite $\left(\mathrm{Co}_{3} \mathrm{~S}_{4}\right)$. These minerals are accompanied by pyrite, which is a great source of iron [3], [4].

Several studies on the treatment of copper-cobalt minerals were conducted and-have shown that at $\mathrm{pH}$ (about 4), the flotation of cobalt from sulfide already is best using xanthate collector. When using nitrosonaphthol chelating reagents, the flotation of cobalt oxides from already is best at the $\mathrm{pH}$ of about 7.5 [4].

The flotation foam of a mineral sulphide $\mathrm{Cu}-\mathrm{Co}$ produce a $\mathrm{Cu}-\mathrm{Co}$ bulk concentrate. During the flotation, $\mathrm{Cu}-\mathrm{Co}$ float at natural $\mathrm{pH}$ or $\mathrm{pH} 11$ using xanthate or dithiophosphate. This occurs when the copper mineralization as chalcocite. Thereafter separating copper and cobalt in the bulk concentrate is done by raising the $\mathrm{pH}$ to at least 11 , which depresses the cobalt minerals. It has been shown that xanthates float better the cobalt minerals at $\mathrm{pH}=11$ and dithiophosphates do at natural $\mathrm{pH}$ [4].

In this study, we collected samples in the mine of Kalukuluku in Lubumbashi in the Democratic Republic of Congo. Chalcocite is abundant copper mineral and carrolite is abundant mineral cobalt. For flotation tests, potassium amylxanthate (PAX: $\mathrm{C}_{5} \mathrm{H}_{11} \mathrm{OCS}_{2} \mathrm{Na}$ ) family of xanthates and sodium amyl dithiophosphate (DANA: $\mathrm{C}_{8} \mathrm{H}_{18} \mathrm{O}_{2} \mathrm{PS}_{2} \mathrm{Na}$ ) family dithiophosphates were used as collectors. Polypropylene glycol methyl ether (Dowfroth 250: DF250) was used as foaming and sodium silicate $\left(\mathrm{Na}_{2} \mathrm{SiO}_{3}\right)$ as depressing and dispersant. Slaked lime $\left(\mathrm{Ca}(\mathrm{OH})_{2}\right)$ was used as a $\mathrm{pH}$ regulator. The latter was varied keeping all other parameters constant: particle size, pulp density, impeller speed, reagents doses (PAX, DF250).

Flotation kinetics was treated for study the variation of the cumulative recovery of a component (copper and cobalt) proportionally to flotation time [18], as a time-rate recovery process.

\section{MATERIALS AND METHODS}

\section{A. Sample}

The ore sample on which we worked was from mine of Kalukuluku in Lubumbashi in the Democratic Republic of Congo. It has been crushed in a laboratory jaw crusher (primary) and then in a cylindrical laboratory crusher (secondary) to have a size $<1.7 \mathrm{~mm}$. We collected $25 \mathrm{~kg}$ for the result of our tests. The X-ray diffraction analysis revealed the presence of chalcopyrite $\mathrm{CuFeS}_{2}$, of chalcocite $\mathrm{Cu}_{2} \mathrm{~S}$ and Carrolite $\mathrm{CuCo}_{2} \mathrm{~S}_{4}$ as sulphides. The matrix was made of quartz $\mathrm{SiO}_{2}$, Dolomite $\mathrm{CaMg}\left(\mathrm{CO}_{3}\right)_{2}$, Feldspar $\mathrm{AlSi}_{3} \mathrm{O}_{8}$ and talc $\mathrm{Mg}_{3} \mathrm{Si}_{4} \mathrm{O}_{10}(\mathrm{OH})_{2}$. After analysis by atomic-absorption ICP, the contents of Table 1 have been revealed. 
Table 1: Chemical analysis of the sample by AAS/ICP

\begin{tabular}{cc}
\hline Elements & Contents $(\%)$ \\
\hline $\mathrm{Cu}_{\mathrm{T}}$ & 3.57 \\
\hline $\mathrm{Cu}_{\mathrm{Ox}}$ & 0.4 \\
\hline $\mathrm{Co}_{\mathrm{T}}$ & 0.39 \\
\hline $\mathrm{Co}_{\mathrm{ox}}$ & 0.01 \\
\hline $\mathrm{Fe}$ & 2.94 \\
\hline $\mathrm{Mn}$ & 0.13 \\
\hline $\mathrm{Ca}$ & 9,765 \\
\hline
\end{tabular}

\section{B. Reagents}

PAX and DANA were used as collectors and have been prepared at $1 \%$ by dissolving $1 \mathrm{~g}$ in $100 \mathrm{ml}$ of water. $\mathrm{Na}_{2} \mathrm{SiO}_{3}$ was used as depressing and dispersant and was prepared at $30 \%$ by dissolving $30 \mathrm{~g}$ in $100 \mathrm{ml}$ of water. $\mathrm{Ca}(\mathrm{OH})_{2}$ as a $\mathrm{pH}$ regulator was prepared at $20 \%$ by dissolving $20 \mathrm{~g}$ of $\mathrm{CaO}$ in $100 \mathrm{ml}$ water. DF250 has been used as frother. Tap water was used for the flotation tests. Equation (1) was used for the passage of $\mathrm{g} / \mathrm{t}$ to $\mathrm{ml}$ for each reagent.

$V=\frac{\text { mass of ore sample }(\mathrm{kg}) \times \text { reagent dose }(\mathrm{g} / \mathrm{t})}{\text { reagent concentration }(\mathrm{g} / 1)}$

\section{Equipment}

The following equipment was used: a laboratory mill (length: $260 \mathrm{~mm}$, diameter: $180 \mathrm{~mm}$, rotation speed: 100 rpm), a flotation machine DENVER, flotation cell of $2.5 \mathrm{~L}$, panels, an VIBRA electronic balance, graduated vessels for reagents, a $\mathrm{pH}$ meter, a propipette, a wash bottle of 1 liter, a pallet.

\section{Grinding}

$1 \mathrm{~kg}$ of sample was mixed with 11 of water in the mill with $50 \%$ solids into the mill. This grinding was carried out at different times 15, 20 and 25 minutes respectively. The pulp from the mill was placed on a sieve of $75 \mu \mathrm{m}$ and then the refusing was oven dried and weighed. According to Fig. 1, grinding curve was plotted by varying the refusing $75-\mu \mathrm{m}$ size vs time.

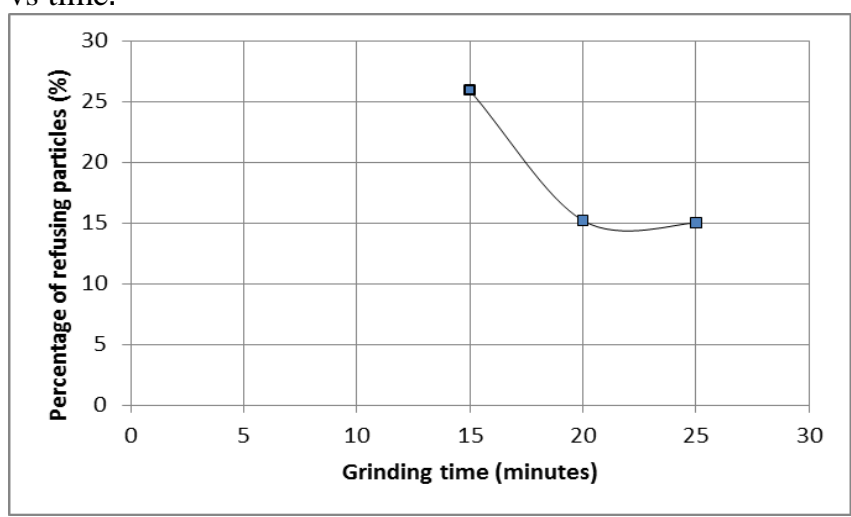

Fig.1: Grinding curve's ore of Kalukuluku

For our flotation tests, we had considered $20 \%$ of refusing on the sieve of $75 \mu \mathrm{m}$. And in view of Fig. 1, 18 minutes of grinding has been required.

\section{E. Flotation test}

Before the flotation tests in single roughing, $\mathrm{pH}$ meter has been calibrated. The ore was ground for 18 minutes. The pulp was placed into the flotation cell of $2.5 \mathrm{~L}$. Having lowered the rotor into the pulp, we operated the operation at $1300 \mathrm{rpm}$. We added $\mathrm{Na}_{2} \mathrm{SiO}_{3}$ conditioned for 3 minutes and $\mathrm{Ca}(\mathrm{OH})_{2}$ for $\mathrm{pH}$ regulation. Note that have worked at natural $\mathrm{pH}$ and $\mathrm{pH}$ 11. Then collector $(45 \mathrm{~g} / \mathrm{t})$ and frother (5 drops) were added conditioned for 2 minutes. After that, we opened the air valve at $5 \mathrm{~L}$ per min and collected concentrates in fractions of $0.5 ; 0.5 ; 1 ; 1 ; 2 ; 2$ and 2 minutes respectively. The first 4 fractions were made the head concentrate. All concentrates and tailings were sent to the laboratory for chemical analysis by AAS-ICP to determine the amounts of copper and cobalt. The $60 \mathrm{~g} / \mathrm{t}$ corresponding to the remaining collector were added after the recollections fractions coming after the first, during a conditioning time of one minute. The flotation kinetics was also evaluated for comparison between PAX and DANA in recovery of copper and cobalt, using the variation of constant rate vs time. The flotation scheme in simple roughing is shown by the Fig. 2 .
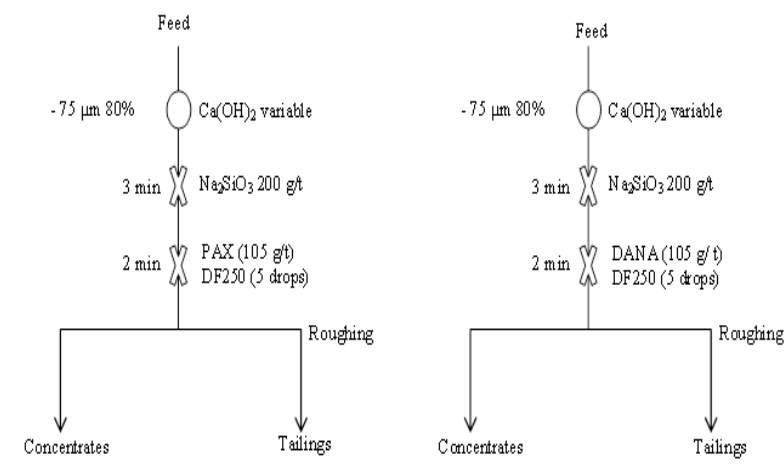

Fig.2: Diagram of single roughing flotation tests

\section{RESULTS AND DISCUSSION}

\section{A. Variations recovery vs time and grade vs time}

Fig. 2 was used to study concerned variations by changing every time the $\mathrm{pH}$ using $\mathrm{Ca}(\mathrm{OH})_{2}$. We worked in at natural $\mathrm{pH}$ and $\mathrm{pH}=11$. The other parameters were kept constant: $\mathrm{d}_{80}=75$ $\mu \mathrm{m}, \operatorname{PAX}(105 \mathrm{~g} / \mathrm{t}), \mathrm{DF} 250$ (5 drops), pulp density $10 \%$ solids and impeller speed of $1300 \mathrm{rpm}$. The pulp produced by milling for 18 minutes was placed in $2.5 \mathrm{~L}$. $\mathrm{Ca}(\mathrm{OH})_{2}$ was added (only to adjust $\mathrm{pH}$ to 11 ), PAX and DF250 was added conditioned for 5 minutes. Then the air intake was introduced at $5 \mathrm{~L}$ per min. Finally, concentrates and tailings were collected, sent to laboratory for analysis by ICP-AAS to determine grades of copper and cobalt, as well as recovery yields.

1) Variations for copper

Figs. 3 and 4 show results of recovery and grade of copper vs time at different $\mathrm{pH}$ values.

By comparison with the results of Fig. 3 and 4, we note that at natural $\mathrm{pH}$, copper recovery is fast with DANA until the fifth minute. After the fifth minute, recovery of copper with PAX is better and gives a concentrate at $16.1 \%$ with a yield of $99.63 \%$. At $\mathrm{pH} 11$, the curve of the PAX is better than DANA, giving a concentrate at $16.1 \%$ copper with a yield of $99.05 \%$.

Thus, the copper recovery is quick at natural $\mathrm{pH}$ with the DANA until the fifth minute. After the fifth minute of flotation, the PAX is better. At $\mathrm{pH}=11, \mathrm{PAX}$ have a good selectivity. 


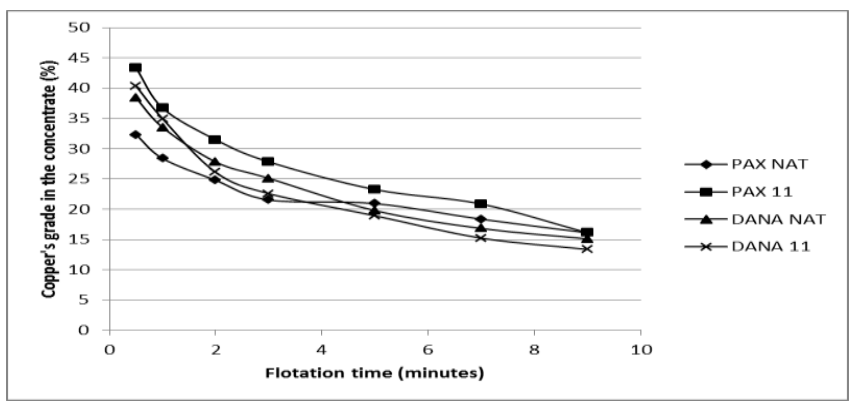

Fig. 3 : Variation of copper's grade vs time at different $\mathrm{pH}$ values

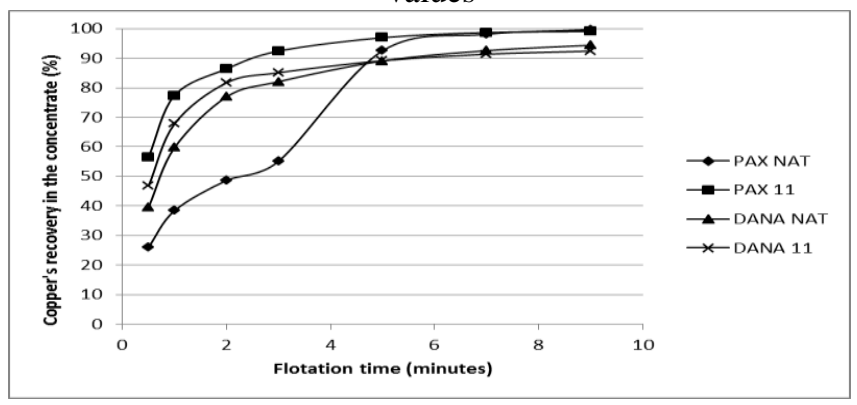

Fig. 4 : Variation of copper's recovery vs time at different $\mathrm{pH}$ values

These results confirmed that the flotation by PAX is steady in an alkaline medium condition [16].

\section{2) Variations for cobalt}

Figs. 5 and 6 show results of recovery and grade of cobalt vs time at different $\mathrm{pH}$ values.

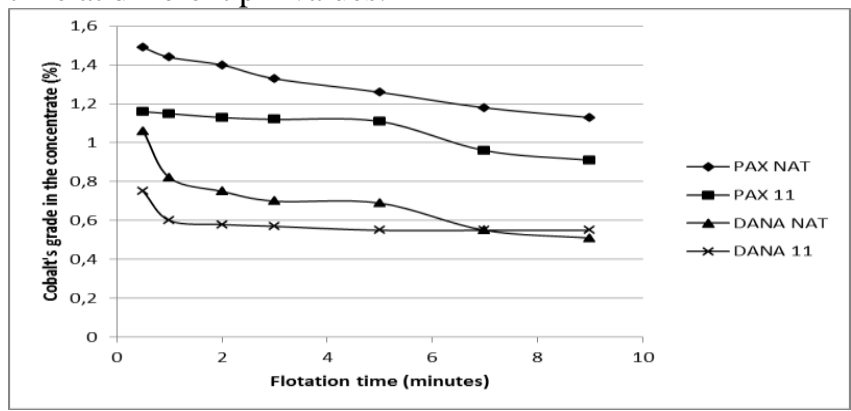

Fig.5 : Variation of cobalt's grade vs time at different $\mathrm{pH}$ values

According to Fig. 5 and 6, we observe that at natural pH, selectivity of DANA is higher than selectivity of PAX. Cobalt recoveries for both collectors are almost the same to the third minute and beyond the third minute, the growth recovery is more pronounced for DANA than for PAX.

Thus, with DANA, we obtain a concentrate at $0.51 \%$ cobalt at a yield of $76.48 \%$. With PAX, $1.13 \%$ cobalt concentrate is obtained with a yield of $47.37 \%$.

At $\mathrm{pH}=11, \mathrm{PAX}$ is largely better from the beginning to the end of cobalt recovery. It gives a concentrate at $0.91 \%$ cobalt with a yield of $85.18 \%$, it is most selective.

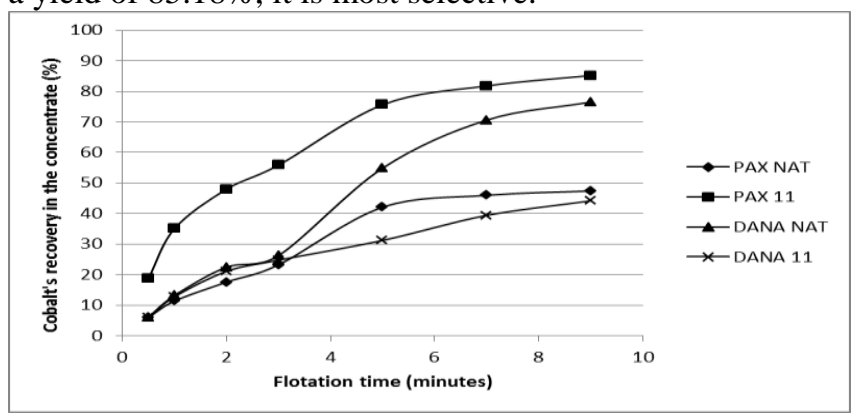

Fig.6 : Variation of cobalt recovery vs time at different $\mathrm{pH}$ values
At $\mathrm{pH}=11, \mathrm{PAX}$ is largely better from the beginning to the end of cobalt recovery. It gives a concentrate at $0.91 \%$ cobalt with a yield of $85.18 \%$, it is most selective. This confirms the study [14] who said that the alkaline $\mathrm{pH}$ depresses pyrite in the presence of xanthates, increasing the selectivity of the used collector.

\section{B. Determination of flotation rate constant}

Several authors have investigated the first order flotation kinetics models [1], [6], [8], [10], [12]-[13]. Among those models, the classic model is investigated for our study and according to this model; we have calculated the first order rate constant $\mathrm{k}$ from equation (2).

[2] and [7] have shown that the flotation kinetics studies the quantitative variation of the recovery $\mathrm{R}$ of the floatable mineral in concentrate vs time $t$.

$R=R_{s o}\left(1-e^{-k t}\right)$

where $R_{x s}$ is the maximum recovery achievable or the cumulative recovery at time infinite $(\%), \mathrm{R}$ is the recovery at time $\mathrm{t}(\%), \mathrm{k}$ is the first order rate constant $\left(\mathrm{s}^{-1}\right), \mathrm{t}$ is the flotation time (s). After developing the formula (2), we obtain equation (3).

$\mathrm{kt}=-\ln \left(1-\frac{\mathrm{R}}{\mathrm{R}_{\mathrm{gmo}}}\right)$

In the case of our study, we evaluate the variation of the factor $-\ln \left(1-\frac{R}{R_{w}}\right)$ vs flotation time to find the rate constant $k$, both for copper and cobalt.

\section{1) For copper}

According to Fig. 7, at natural $\mathrm{pH}$, the flotation rate constant is better by DANA till the $5^{\text {th }}$ minute and after that, the flotation rate by PAX increased till the end of flotation. At $\mathrm{pH}=11$, the flotation rate is largely best by PAX than by DANA. In copper recovery, the rate flotation constant is higher by $\mathrm{PAX}$ at natural $\mathrm{pH}\left(0.634 \mathrm{~s}^{-1}\right)$ and $\mathrm{pH}=11(0.443$ $\left.\mathrm{s}^{-1}\right)$. Another very important observation concerning PAX is that its faster kinetics in the recovery of copper both at natural $\mathrm{pH}$ and at $\mathrm{pH}=11$.

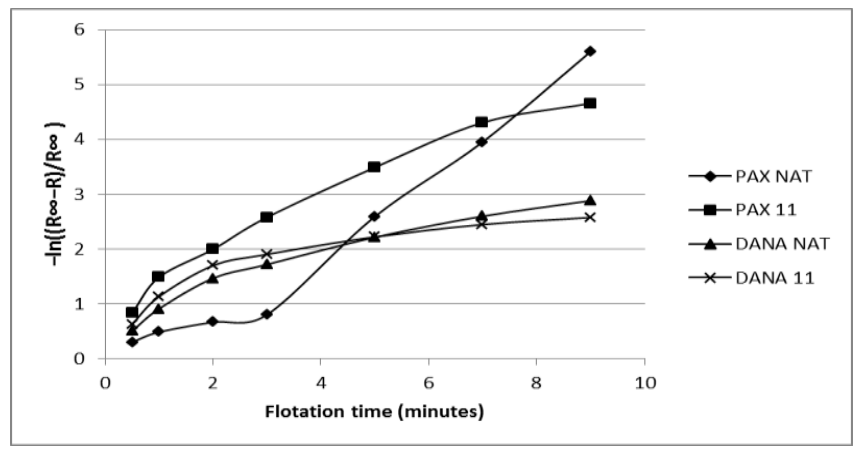

Fig. 7 : Determination of rate constant in flotation of copper at different $\mathrm{pH}$ values

In both the values of $\mathrm{pH}$, the first order rate constant for copper recovery by PAX was found to be higher than that by DANA.

\section{2) For cobalt}

Fig. 8 shows that the rate flotation constant is better by DANA at natural $\mathrm{pH}$ and by $\mathrm{PAX}$ at $\mathrm{pH}=11$ from the 
beginning to the end of flotation. Another confirmation is that the rate flotation constant increases rapidly after the third minute by DANA at natural $\mathrm{pH}$.

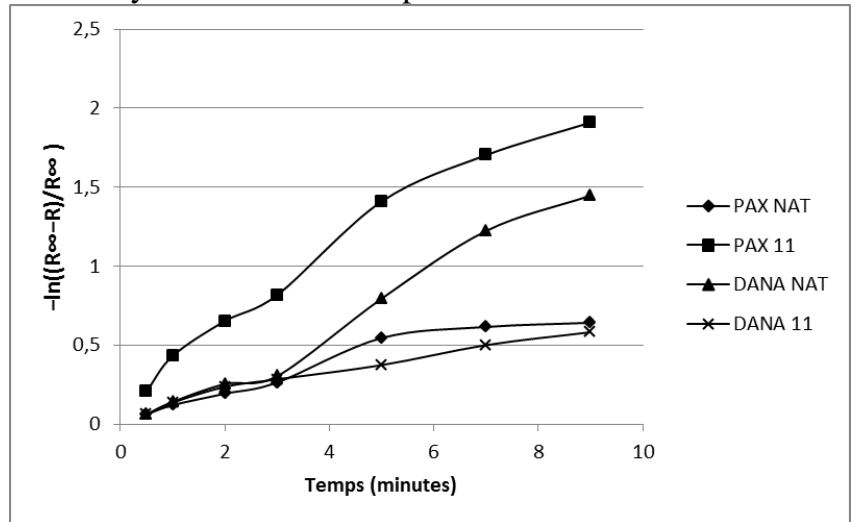

Fig.8 : Determination of rate constant in flotation of cobalt at different $\mathrm{pH}$ values

In cobalt recovery, the rate flotation constant is higher by DANA at natural $\mathrm{pH}\left(0.172 \mathrm{~s}^{-1}\right)$ and by $\mathrm{PAX}$ at $\mathrm{pH}=11(0.203$ $\left.\mathrm{s}^{-1}\right)$.

\section{CONCLUSION}

This study was intended to compare the selectivity and kinetics of PAX and DANA in recovery of copper and cobalt from a sulfide Copper-Cobalt ore. Keeping the particle size, pulp density, impeller speed, and reagents doses as constant parameters, only the $\mathrm{pH}$ was varied from the natural and $\mathrm{pH}=11$. At natural $\mathrm{pH}, \mathrm{PAX}$ was given the good results for the recovery of copper obtaining a concentrate of $16,1 \%$ with a yield of $99,63 \%$ and a flotation rate constant of $0,634 \mathrm{~s}^{-1}$. For the recovery of cobalt, DANA was found as better collector obtaining a concentrate of $0.51 \%$ with a yield of $76.48 \%$ and a flotation rate constant of $0,172 \mathrm{~s}^{-1}$. At $\mathrm{pH}=11$, PAX was found as the better collector for the recovery of both copper and cobalt obtaining concentrates of $16,1 \% \mathrm{Cu}$ and $0,91 \% \mathrm{Co}$ respectively. The flotation yields were $99,05 \%$ and $85,18 \%$ respectively. Flotation rate constants were $0,443 \mathrm{~s}^{-1}$ and 0,203 $\mathrm{s}^{-1}$ respectively. According to these results, it is clearly shown that at both natural $\mathrm{pH}$ and $\mathrm{pH}=11$, the kinetic of copper recovery is better by PAX than by DANA. However, for the kinetic of cobalt, DANA is better than PAX at natural $\mathrm{pH}$. It is therefore recommended that a kinetic study be further undertaken in acidic conditions.

\section{ACKNOWLEDGMENT}

Authors thank the company Chemical of Africa that has opened the doors for the samples and the laboratory.

\section{REFERENCES}

[1] A. Agar, G. E. Chia, and C. L. Requis. (1988). Flotation rate measurements to optimize an operating circuit. Minerals Engineering, 11(4), 347-360

[2] I. Bobin and N. Petrovskaya. (2008). Usage of inertial model of $1^{\text {st }}$ order with delay for analysis of kinetics of flotation.

[3] S. M. Bulatovic, C. J. Ferron, and W. T. Yen. (1992, August 2-6). Development and Plant Application of New Collector for Oxide Copper/Cobalt Ore Flotation for Gecamines, Zaire Flotation Plants, Copper 92, Ottawa.

[4] S.M. Bulatovic. "Handbook of Flotation Reagents, Chemistry, Theory and Practice: Flotation of Sulfide Ores", Elsevier Science \& Technology Books, Vol.1, 2007, pp. 5-31, 105-109, 177-178, 235-239.
[5] W. L. Cornell and D. C. Holtgrefe. (1989). Continuous Flotation Testing to Recover a Bulk Sulfide Concentrate from Missouri Lead Ore Tailings, U.S. Bur. Mines, R1 9265.

[6] E. C. Dowling, R. R. Klimpel and F. F. Aplan, (1985). Model discrimination in the flotation of a porphyry copper ore. Minerals and Metallurgical Processing, 2(2), 87-101

[7] M. Gharai and R. Venugopal. (2016). Modeling of flotation process-An overview of different approaches. Mineral Processing and Extractive Metallurgy Review, Vol. 37, ํ2, pp. 120-133.

[8] C. J. Jameson, S. Nam and M. M. Young. (1977). Physical factors affecting recovery rates in flotation. Miner. Sci. Eng., Vol. 9, $\mathrm{N}^{\circ} 3$, $103-118$

[9] H. Kazutoshi, T. William and S. Atsushi. (2012). Investigation of Flotation Parameters for Copper Recovery from Enargite and Chalcopyrite Mixed Ore Materials Transactions, The Japan Institute of Metals, Vol. 53, N4, pp. 707 to 715

[10] A. Krstev, B. Krstev, Z. Zdravev, S. Ferat, J. Zivanovik and Z. Gocev. (2013, June 12-16). The kinetic flotation modelling of chalcopyrite from domestic ores using software tools, Proceedings of the XV Balkan Mineral Processing Congress, Sozopol, Bulgaria.

[11] R. Z. Liu, W. Q. Qin, F. Jiao, X. J. Wang, P. Bin, Y. J. Yang and C. H Lai. (2016). Flotation separation of chalcopyrite from galena by sodium humate and ammonium persulfate. Trans. Nonferrous Met. Soc. China, Vol. 26, pp. 265-271.

[12] R. Natarajan and I. Nirdosh. (2006). A Comparative Study of Kinetics of Flotation of a Copper-Nickel Ore by N-Hydrocinnamoyl-N-Phenylhydroxylamine (HCNPHA) Vis-A-Vis Potassium Amyl Xanthate (PAX), Proceedings of the International Seminar on Mineral Processing Technology, Chennai, India. pp. 236-242

[13] M. Polat and S. Chander. (2000). First-order flotation kinetics models and methods for estimation of the true distribution of flotation rate constants. International Journal of Mineral Processing, Vol. 58, pp. $145-166$

[14] W. Trahar, G. Senior and L. Shannon. (1994). Interactions between sulphide minerals-the collectorless flotation of pyrite. International Journal of Mineral Processing, Vol. 40, №3-4, pp. 287-321

[15] M. Villena and G. Fernando. (2018). On Resource Depletion and Productivity; The Case of the Chilean Copper Industry. Resource Policy, Vol. 59, p. 553

[16] B. A. Wills. Mineral processing Technology. New York: Pergamon Express, 1988.

[17] W. Xinrong, T. Changqing and Z. Yujun. (2019). IOP Conf. Series: Earth and Environmental Science 237032104.

[18] X. M. Yuan, B. J. Palsson and K. S. E. Forssberg. (1996). Statistical interpretation of flotation kinetics for a complex sulphide ore. Minerals Engineering, Vol. 9, $\mathrm{N}^{\circ} 4$, pp. 429-442

[19] C. Zhang, N. Song, G. M. Zeng, M. Jiang, J. C. Zhang, X. J. Hu and J. M. Zhen. (2014). Bioaccumulation of zinc, lead, copper, and cadmium from contaminated sediments by native plant species and Acrida cinerea in South China. Environ. Monit. Assess., Vol 186, pp. $1735-1745$.

[20]

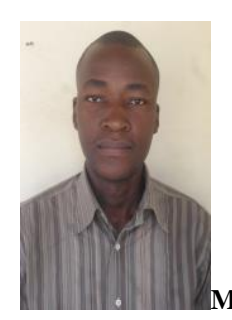

Meschack Muanda Mukunga: Graduate Engineer in Department of chemical and metallurgical Engineering at University of Lubumbashi since year 2016. Secondary school was done and completed in Imara Institute in Lubumbashi/ DRCongo since 2009. Graduate has been done at University of Lubumbashi in july 2016. Actually Master student (student number 2060556) at in department of chemical and metallurgical engineering, University of the Witwatersrand in Johannesburg/South Africa.

About research, "Optimization of current efficiency in electrowinning of copper" has been done at MMG company (Kinsevere Mine) in year 2014 Assistant teacher of Omalanga Pele Pascal Daniel who is teacher at University of Lubumbashi since 2016 